\title{
Decision-making problems of recipients of railway freight transport outsourcing services
}

\section{Problemy decyzyjne odbiorców usług outsourcingu transportu kolejowego ladunków}

\begin{abstract}
Surviving on the market and gaining a competitive advantage require the effective management that guarantees the success of the company. Outsourcing is one of the methods. The term outsourcing derives from English and is an abbreviation of the expression outside resource using, which means the use of external resources. Outsourcing should focus on optimization of costs and employment. The main benefit should be the pursuit of increased flexibility of structures, access to the qualified staff and other resources of the company. Failures of outsourcing may result both from the side of the ordering company and providing railway freight transport services. The empirical studies on decision-making problems of recipients of railway freight outsourcing services allowed to identify the benefits, risks, communication methods and problems in partner cooperation.

Przetrwanie na rynku i zdobycie przewagi konkurencyjnej wymagaja efektywnego zarzqdzania gwarantujacego sukces przedsiębiorstwu. Jednq z metod jest outsourcing. Określenie outsourcingu pochodzi z języka angielskiego i jest skrótem wyrażenia outside resource using oznaczajacego wykorzystanie zasobów zewnętrznych. Outsourcing powinien się koncentrować na optymalizacji kosztów i zatrudnienia. Glówna korzyściq powinno być dażenie do zwiększonej elastyczności struktur, dostęp do wykwalifikowanej kadry pracowniczej oraz innych zasobów przedsiębiorstwa. Niepowodzenia outsourcingu moga wynikać zarówno ze strony przedsiębiorstwa zlecajqcego i świadczqcego ustugi transportu kolejowego ładunków. Badania empiryczne dotyczqce problemów decyzyjnych odbiorców ustug outsourcingu transportu kolejowego ladunków pozwolity zidentyfikować korzyści, ryzyko, sposób komunikacji oraz problemy we wspótpracy partnerskiej.
\end{abstract}

\section{Introduction}

Outsourcing was already realized in the antiquity by making a simple division of work. The name of outsourcing was created three decades ago and comes from the English words - outside resource using. In the economic sciences the outsourcing appeared in the eighteenth century. Adam Smith in the work entitled "The wealth of nations" paid attention to the competitive advantage of some companies over the others which leads in a given unit to reduce the production costs. The precursor of outsourcing was Henry Ford, who said: "if there is something that we cannot do more efficiently, cheaper and better than our competitors, it makes no sense to do it and we should employ someone to carry out this work better than we do."

It should be noted that the concept of outsourcing initially concerned the production processes and then included the services and service business processes such as HR (human resources), IT (information technology), accounting, finance and customer service. In

\section{Wprowadzenie}

Outsourcingu realizowany był już w starożytności poprzez dokonywanie prostego podziału pracy. Nazwa outsourcingu powstała trzy dekady temu i pochodzi od wyrazów angielskich - outside resource using. W naukach ekonomicznych outsourcing pojawił się w XVIII wieku. Adam Smith w dziele Bogactwo narodów zwrócił uwagę na konkurencyjną przewagę jednych firm nas drugimi, która prowadzi w danej jednostce do ograniczenia kosztów produkcji. Prekursorem outsourcingu był Henry Ford, który stwierdził: "ze jeśli jest coś czego nie potrafimy zrobić wydajniej, taniej $i$ lepiej niż nasi konkurenci nie ma sensu, żebyśmy to robili i powinniśmy zatrudnić do wykonania tej pracy kogoś, kto zrobi to lepiej niz my".

Należy zauważyć, że pojęcie outsourcingu początkowo dotyczyło procesów produkcyjnych, a następnie obejmowało usługi i usługowe procesy biznesowe takie jak: HR (human resources), IT (information technology), księgowość, finanse oraz obsługę klienta. 
Poland Michał Trocki introduced the concept of outsourcing for the first time, defining it: "as a venture consisting in separating from the organizational structure of the parent company the functions that are realized by it and transferring them to other economic entities" [2].

It should be emphasized that the literature presents the numerous definitions and views related to this concept. Outsourcing is not only identified with the separation of functions and tasks of the parent company and transferring them to the external companies to be realized, but it also may be defined as a contract for the performance of specific products or realization of services by the external company [3]. A strategic longterm alliance between the company - the customer and the company - the supplier of goods and services [8] can be seen as acquiring the production forces [9]. It should be stated that the provision of outsourcing services of railway freight transport to other commercial, production and service enterprises is defined as a contract for the performance of specific products or provision of services by the external company. Decisionmaking problems of recipients of railway freight transport outsourcing services concern, first of all, the determination of benefits as a result of transport services realized outside the enterprise, the risk of failure of cooperation with the external company, the problems in partnership cooperation and the contact between the business partners.

\section{Benefits and failures of outsourcing}

The cost factors are most frequently the main motive for the provision of outsourcing services. Restructuring of companies based on the outsourcing allow to reduce the costs, and in the longer perspective to restore the profitability of enterprises that are in danger of liquidation. Another advantage is the possibility of focusing on own core activity, searching for skills and resources not available in the company, limiting the risk of conducted activity due to the partial transfer of services to the contractor. The main motives for making the decisions about outsourcing are as follows (own study based on $[1,5]$ ):

1. Reduction and control of operating costs.

2. Focusing on the core activity.

3. Access to the resources to which the parent company does not have.

4. Risk limitation by transferring the partial responsibility to the contractor.

5. Reorganization of the business processes.

6. Thanks to the outsourcing services we are more available to clients.

The benefits of providing the outsourcing services are presented below (the own study based on $[1,7]$ :

- higher efficiency

- improving the activity of the parent company
W Polsce po raz pierwszy wprowadził pojęcie outsourcingu Michał Trocki definiując je: ,jako przedsięwzięcie, polegajace na wydzieleniu ze struktury organizacyjnej przedsiębiorstwa macierzystego realizowanych przez nie funkcji i przekazanie ich do wykonania innym podmiotom gospodarczym" [2].

Należy podkreślić, że literaturze prezentowane są liczne definicje i poglądy związane z tym pojęciem. Outsourcing nie jest jedynie utożsamiany $\mathrm{z}$ wydzieleniem funkcji i zadań przedsiębiorstwa macierzystego i przekazaniem ich do realizacji firmom zewnętrznym, ale również może być określany jako kontrakt na wykonanie określonych produktów lub realizację usług przez firmę zewnętrzną [3]. Strategiczny wieloletni alians między firmą - klientem, a firmą - dostawca dóbr i usług [8] może być postrzegany jako pozyskiwanie sił wytwórczych [9]. Należy stwierdzić, że świadczenie usług outsourcingu transportu kolejowego ładunków innym przedsiębiorstwom handlowym, produkcyjnym i usługowym jest określane jako kontrakt na wykonanie określonych produktów lub realizacje usług przez firmę zewnętrzną. Problemy decyzyjne odbiorców usług outsourcingu transportu kolejowego ładunków dotyczą przede wszystkim określenia korzyści w wyniku realizacji usług transportowych na zewnątrz przedsiębiorstwa, ryzyka niepowodzenia współpracy $\mathrm{z}$ firmą zewnętrzną, problemów we współpracy partnerskiej oraz kontaktu pomiędzy partnerami biznesowymi.

\section{Korzyści i niepowodzenia outsourcingu}

Głównym motywem świadczenia usług outsourcingowych są najczęściej czynniki kosztowe. Restrukturyzacja przedsiębiorstw oparta na outsourcingu pozwala zredukować koszty, a w dłuższej perspektywie przywrócić rentowność przedsiębiorstw, którym grozi likwidacja. Inną zaletą jest możliwość skoncentrowania się na swojej podstawowej działalności, poszukiwanie umiejętności i zasobów niedostępnych w przedsiębiorstwie, ograniczenie ryzyka prowadzonej działalności ze względu na częściowe przerzucenie usług na zleceniobiorcę. Główne motywy podejmowania decyzji o outsourcingu są następujące (opracowanie własne na podstawie $[1,5])$ :

1. Redukcja i kontrola kosztów operacyjnych.

2. Koncentracja na podstawowej działalności.

3. Dostęp do zasobów, do których nie posiada przedsiębiorstwo macierzyste.

4. Ograniczenie ryzyka poprzez przeniesienie częściowej odpowiedzialności na zleceniobiorcę.

5. Reorganizacja procesów biznesowych.

6. Dzięki usługom outsourcingowym jesteśmy bardziej dyspozycyjni dla klientów.

Korzyści ze świadczenia usług outsourcingowych przedstawiono poniżej (opracowanie własne na podstawie $[1,7]$ : 
- the possibility of the company's focus on key tasks and functions, services

- access to the professional knowledge not available in the company

- increasing the flexibility of the conducted activity

- increasing the quality of services realized so far

- acquiring the new skills

- stability in employment of the company's employees

- greater profit for the company commissioning the outsourcing services.

It should be noted that outsourcing can be treated as a way to improve the functioning of the company, however, often some companies are forced to withdraw from the outsourcing strategy. Failures of outsourcing services are often connected with partner cooperation between the client and the contractor. Failures concerning the outsourcing of services are listed below (own study based on [2, 6]:

- wrongly identified risk

- lack of professional and specialist knowledge about outsourcing

- excessive hurry

- cultural differences

- lack of clearly defined customer needs and expectations of outsourcing services

- failure to fulfill the provisions of the outsourcing contract

- wrong management in the partner cooperation

- lack of a joint planning stage of the outsourcing project between the business partners

- wrong communication between the client and the contractor

- disrespect for the interests of the parties to the contract concerning the quality of services

- wrongly selected external advisers

- errors in initiation of outsourcing contract

- not informing about the individual stages of outsourcing

- lack of involvement of the best managers in the outsourcing process.

The wrong planning and preparation of the outsourcing contract is one of the most common causes of its failure. The strategy and preparation of the company for outsourcing cooperation play very important role.

\section{Own studies}

Empirical studies on decision-making problems of recipients of railway freight transport outsourcing services were carried out at the Silesian University of Technology [4] in 2012-2013. The studies covered the production and trade enterprises using the railway freight transport outsourcing services and the railway
- większa wydajność

- usprawnienie działalności przedsiębiorstwa macierzystego

- możliwość skoncentrowania się przedsiębiorstwa na kluczowych zadaniach i funkcjach, usługach

- dostęp do fachowej wiedzy niedostępnej w przedsiębiorstwie

- zwiększenie elastyczności prowadzonej działalności

- podwyższenie jakości realizowanych dotychczas usług

- pozyskanie nowych umiejętności

- stabilność w zatrudnieniu pracowników przedsiębiorstwa

- większy zysk dla przedsiębiorstwa zlecającego usługi outsourcingowe.

Należy zauważyć, że outsourcing może być traktowany jako sposób na poprawę funkcjonowania przedsiębiorstwa, jednak często niektóre przedsiębiorstwa są zmuszone do wycofania się ze strategii outsourcingowej. Niepowodzenia realizacji usług outsourcingowych często są związane ze współpracą partnerską zleceniodawcy i zleceniobiorcy. Niepowodzenia dotyczące outsourcingu usług zestawiono poniżej (opracowanie własne na podstawie $[2,6]$ :

- nieprawidłowo zidentyfikowane ryzyko

- brak fachowej i specjalistycznej wiedzy o outsourcingu

- nadmierny pośpiech

- różnice kulturowe

- brak jasno określonych potrzeb i oczekiwań klienta usług outsourcingowych

- nie wywiązanie się $\mathrm{z}$ postanowień umowy outsourcingowej

- niewłaściwe zarządzanie we współpracy partnerskiej

- brak wspólnego etapu planowania projektu outsourcingowego pomiędzy partnerami biznesowymi

- niewłaściwa komunikacja pomiędzy zleceniodawcą i zleceniobiorcą

- nieposzanowanie interesów stron umowy dotyczącej jakości usług

- niewłaściwie dobrani doradcy zewnętrzni

- błędy w inicjacji umowy outsourcingowej

- nieinformowanie o poszczególnych etapach realizacji outsourcingu

- brak zaangażowania najlepszych menedżerów w proces outsourcingowy.

Nieprawidłowe zaplanowanie i przygotowanie umowy outsourcingowej to jeden $\mathrm{z}$ najczęstszych powodów jego niepowodzenia. Istotne znaczenie odgrywa strategia i przygotowanie przedsiębiorstwa do współpracy outsourcingowej. 
transport company. The conducted studies allowed to identify the benefits as a result of the provision of railway freight services, the risk and problems in the partner cooperation and the way of contact dominating in the relations between the service provider and the client.

The benefits (according to carried out empirical research) resulting from realization of transport services outside companies are presented in Fig. 1.

As it appears from the above:

- the reduction of costs was the greatest benefit $-21,3 \%$ of indications

- higher quality of realized services $-21,3 \%$ of indications

- increasing the flexibility of conducted activity $-20,6 \%$ of indications

- access to resources unavailable in the company $-19,9 \%$ of indications

- the opportunity to focus on the implementation of key competences was the smallest benefit $-16,9 \%$ of indications.

\section{Badania wlasne}

Badania empiryczne dotyczące problemów decyzyjnych odbiorców usług outsourcingu transportu kolejowego ładunków zostały przeprowadzone na Politechnice Śląskiej [4] w latach 2012 - 2013. Badaniami objęto przedsiębiorstwa produkcyjno - handlowe, korzystające $\mathrm{z}$ outsourcingu usług transportu kolejowego ładunków oraz przedsiębiorstwa transportu kolejowego. Przeprowadzone badania pozwoliły zidentyfikować korzyści w wyniku świadczenia usług transportu kolejowego ładunków, ryzyko i problemy we współpracy partnerskiej oraz sposób kontaktu dominujący w relacjach pomiędzy usługodawcą i usługobiorcą.

Korzyści (według przeprowadzonych badań empirycznych) w wyniku realizacji usług transportowych na zewnątrz przedsiębiorstw przedstawiono na rys. 1 .

6. Jakich korzyoeci oczeku je siê w w yniku rea lizacjius ug transportowych na zew $n^{1}$ trzprzeds iêbiorstwa (m o¿na zaznaczyæ w iêce jn ic jedn ${ }^{1}$ odpow iedÿ)

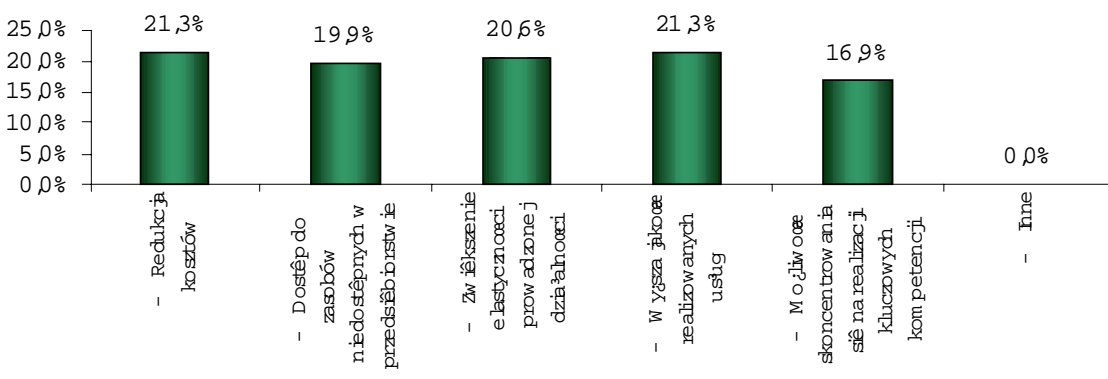

Rys. 1. Korzyści w wyniku realizacji usług transportu kolejowego ładunków
Legend:

6. Jakich korzyści oczekuje się = What benefits are expected

Redukcja kosztów $=$ Costs reduction

Dostęp do zasobów $=$ Access to resources

Zwiększenie elastyczności $=$ Increased flexibility

Wyższa jakość = Higher quality

Możliwość skoncentrowania się = Possibility of concentration

Fig. 1. Benefits resulting from realization of railway freight transport

8. Czy rozpatryw ano ryzyko niepow odzená w spó pracy z firm ${ }^{1}$ zew nêtrzn ${ }^{1}$

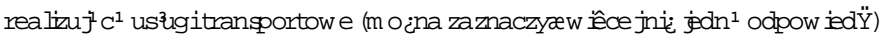

\begin{tabular}{|c|c|c|c|c|c|c|c|}
\hline \multirow[t]{2}{*}{$\begin{array}{r}30.0 \% \\
25.0 \% \\
20.0 \% \\
15.0 \% \\
10.0 \% \\
5.0 \% \\
0.0 \%\end{array}$} & $0.0 \%$ & $25.9 \%$ & $24.1 \%$ & $25.0 \%$ & $25.0 \%$ & $0.0 \%$ & \multirow{2}{*}{$\begin{array}{l}\text { Legend: } \\
\text { 8. Czy rozpatrywano ryzyko niepowodzenia }= \\
\text { Was the risk of failure considered } \\
\text { Nie = No } \\
\text { Wzrost kosztów = Costs increase } \\
\text { Zta jakość świadczonych = Poor quality of } \\
\text { provided services } \\
\text { Nieodpowiednie wykorzystanie = Wrong use } \\
\text { Trudny przebieg wspótpracy = Hard course of } \\
\text { cooperation } \\
\text { Inne }=\text { Other }\end{array}$} \\
\hline & $-\mathrm{N}$ ie & $\begin{array}{c}\text { - w zrost kostów } \\
\text { dzia áalnooci } \\
\text { przedsiebiorstwa }\end{array}$ & $\begin{array}{c}-\mathrm{Z}^{3} \text { jakoores } \\
\text { ow iadczonych } \\
\text { przez } \\
\text { zlecenibbiorcê } \\
\text { us ag }\end{array}$ & $\begin{array}{c}\text {-Nieodpow iednie } \\
\text { w ykorzystanie } \\
\text { przez } \\
\text { zleceniobiorcê } \\
\text { poufnych } \\
\text { inform ac ̈̈ }\end{array}$ & $\begin{array}{l}\text { - Trudnyprzebieg } \\
\text { w spó pracyna } \\
\text { poziom ie } \\
\text { operacyjyym }\end{array}$ & - Inne & \\
\hline
\end{tabular}

Rys. 2 Ryzyko niepowodzenia współpracy z firmą zewnętrzną świadczącą usługi transportu kolejowego ładunków

Fig. 2 The risk of failure to cooperate with an external company providing railway freight transport services 


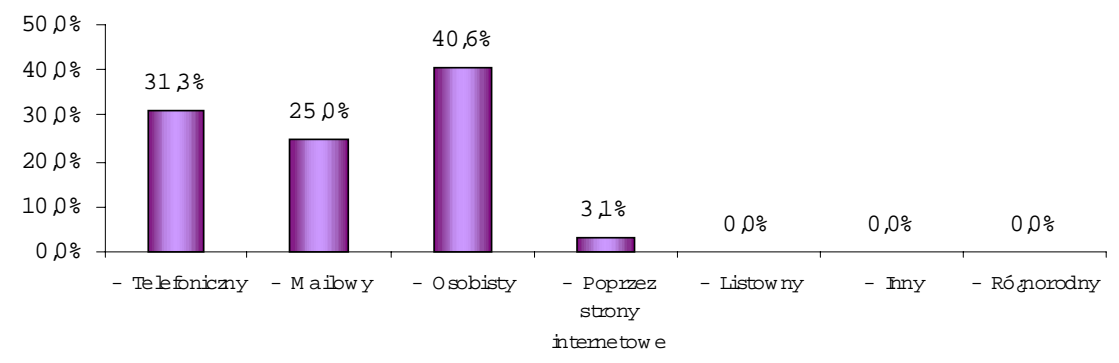

Rys. 3. Formy kontaktu w relacjach pomiędzy usługodawcą i usługobiorca

Fig. 3. Forms of contact in the relations between the service provider and the client
Legend:

5. Jaki sposób kontaktu $=$ How to contact

Telefoniczny $=$ Telephone

Mailowy $=$ E-mail

Osobisty $=$ Personal

Poprzez strony internetowe $=$ Via websites

Listowny = Mail

Inny $=$ Other

Różnorodny $=$ Varied
The reduction of costs and the higher quality of the realized services are two important benefits, as evidenced by the largest number of indications.

The risk of failure to cooperate with an external company providing railway freight transport services is presented in Figure 2.

The risk of failure to cooperate with the external company providing the railway freight transport services, according to all respondents, is related to:

- the increase of the company's activity costs,

- wrong use of confidential information by the contractor and the difficult course of cooperation,

- poor quality of services provided by the contractor.

Figure 3 presents the forms of contact in the relations between the service provider and the client.

As results from the above list, the respondents' assessments are as follows:

- over $40 \%$ of respondents said that the personal contact dominate in the relations between the service provider and the client

- according to $31 \%$ of respondents, the main role was played by the telephone contact

- e-mail contact in the relations between business partners was indicated by $25 \%$ of the respondents

- one person participating in the research thought that this contact takes place via websites

- no e-mail or other diverse contact was noted in the partner relations [4].

Communication in partner cooperation is very important. The relations between the parties arise at the stage of selecting the supplier, and they are formed during the initiation of the outsourcing contract for railway freight transport. An important role in the realization of outsourcing transport services plays the trust between the parties of the contract. The mutual partner relations should be based on trust and openness. The basis of these relationships is, for example, keeping deadlines, solving problems together.
Jak wynika z powyższego:

- największą korzyść stanowiła redukcja kosztów - 21,3\% wskazań

- wyższa jakość realizowanych usług - 21,3\% wskazań

- zwiększenie elastyczności prowadzonej działalności - 20,6\% wskazań

- dostęp do zasobów niedostępnych w przedsiębiorstwie - 19,9\% wskazań

- najmniejszą korzyść stanowiła możliwość skoncentrowania się na realizacji kluczowych kompetencji - 16,9\% wskazań.

Redukcja kosztów i wyższa jakość realizowanych usług to dwie ważne korzyści, o czym świadczy największa liczba wskazań.

Ryzyko niepowodzenia współpracy $\mathrm{z}$ firmą zewnętrzną świadczącą usługi transportu kolejowego ładunków prezentuje rys. 2 .

Ryzyko niepowodzenia współpracy $\mathrm{z}$ firmą zewnętrzną świadczących usługi transportu kolejowego ładunków, według wszystkich respondentów, związane jest $\mathrm{z}$ :

- wzrostem kosztów działalności przedsiębiorstwa,

- nieodpowiednim wykorzystaniem przez zleceniobiorce poufnych informacji i trudny przebieg współpracy,

- złą jakością świadczonych usług przez zleceniobiorce.

Na rysunku 3 przedstawiono $\mathrm{z}$ kolei formy kontaktu w relacjach pomiędzy usługodawcą i usługobiorcą.

Jak wynika z powyższego zestawienia, oceny respondentów są następujące:

- ponad $40 \%$ ankietowanych twierdziło, że kontakt osobisty dominuje w relacjach pomiędzy usługodawcą i usługobiorcą

- według $31 \%$ ankietowanych główną rolę odgrywał kontakt telefoniczny

- kontakt mailowy w relacjach między partnerami biznesowymi wskazało $25 \%$ ankierowanych 


\section{Conclusions}

Empirical studies of decision-making problems of recipients of railway freight transport outsourcing services present the benefits resulting from the outsourcing strategy and the risk and dominant form of the contact between the client's company and the company providing the railway freight services. In summary, it should be remembered that outsourcing should be a strategy ensuring the success of the company. Commonly used forms of contact between the client and the contractor of the railway freight transport services is the transmission of information personally, by phone or by e-mail. It should be noted that outsourcing has its strengths and weaknesses. The advantage of this strategy is to reduce costs, acquire external resources, focus on key areas of the parent company. The most often failures in the implementation of this strategy consist in the lack of planning stage and failure to realize the provisions of individual stages of the outsourcing contract for railway freight transport of outsourcing strategy.

\section{Bibliography / Bibliografia}

[1] Radto M. J., Ciesielska D. A.: Dojrzałość outsourcingowa polskich przedsiębiorstw. Outsourcing Magazine 2010 nr 5 (25).

[2] Ciesielska D., Radto M. J.: Outsourcing w praktyce. Copyright by Poltext Sp. z o.o. Warszawa 2011.

[3] Hiemstra G., Van Tilburg J. J.: Inzicht in uitbesteding: ondernemingsstrategie es besturing Van Gorcum, Assen 1993r.

[4] Markowska K., Merkisz - Guranowska A.: Outsourcing ustug transportu kolejowego. Instytut Technologii Eksploatacji. Państwowy Instytut Badawczy. Radom 2015.

[5] Markowska K.: Badanie wspótpracy w outsourcingu ustug transportu kolejowego - wybrane aspekty. Przeglad Nauk Ekonomicznych. Polskie Towarzystwo Ekonomiczne. Oddziat w Łodzi. Łódź 2017.

[6] Markowska K.: Proponowany przebieg wspótpracy outsourcingowej na przyktadzie transportu kolejowego tadunków. Organizacja i Zarzqdzanie. Zeszyty Naukowe $\mathrm{Nr}$ 1928. Politechnika Ślaska. Gliwice 2015.

[7] Markowska K.: Research on Quality of Cooperation in Outsourcing Services of Railway Undertakings. Journal of Kones. European Science of Powertrain and Transport Publication. Warsaw 2016.

[8] Pańkowska M.: Wspótdziałanie podmiotów rynku produktów $i$ ustug informatycznych. Prace Naukowe Akademii Ekonomicznej w Katowicach. Katowice 1998.

[9] Wesolowski S.: Co to jest outsourcing? Gospodarka Materiałowa i Logistyka nr 11. 2001.
- jedna osoba uczestnicząca w badaniu uważała, że kontakt ten następuje poprzez strony internetowe

- nie odnotowano $\mathrm{w}$ relacjach partnerskich kontaktu listownego, ani innego różnorodnego [4].

Komunikacja we współpracy partnerskiej odgrywa bardzo istotne znaczenie. Relacje pomiędzy stronami powstają już na etapie wyboru dostawcy, a kształtuja się w trakcie inicjacji umowy outsourcingowej transportu kolejowego ładunków. W realizacji usług transportowych outsourcingowych istotną rolę odgrywa zaufanie pomiędzy stronami kontraktu. Wzajemne relacje partnerskie powinny być oparte na zaufaniu, otwartości. Podstawą tych relacji jest np. dotrzymywanie terminów, wspólne rozwiązywanie zaistniałych problemów.

\section{Podsumowanie}

Badania empiryczne problemów decyzyjnych odbiorców usług outsourcingu transportu kolejowego ładunków przedstawiają korzyści wynikające ze strategii outsourcingowej oraz ryzyko i dominująca formę kontaktu pomiędzy przedsiębiorstwem zleceniodawcy i przedsiębiorstwem świadczącym usługi transportu kolejowego ładunków. Reasumując należy pamiętać, że outsourcing powinien być strategią zapewniająca sukces przedsiębiorstwu. Powszechnie stosowanymi formami kontaktu pomiędzy zleceniodawcą i zleceniobiorcą usług transportu kolejowego ładunków jest przekaz informacji osobiście, telefonicznie lub mailowo. Należy zauważyć, że outsourcing ma swoje mocne i słabe strony. Zaletą tej strategii jest dążenie do ograniczenia kosztów, pozyskanie zewnetrznych zasobów, koncentracja na kluczowych obszarach przedsiębiorstwa macierzystego. Najczęstsze niepowodzenia w wdrożeniu tej strategii polegają na braku etapu planowania i nie wywiązywanie się z realizacji postanowień poszczególnych etapów umowy outsourcingowej transportu kolejowego ładunków strategii outsourcingowej. 